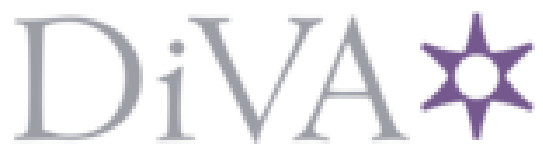

http://www.diva-portal.org

This is the published version of a paper published in Geographical Journal.

Citation for the original published paper (version of record):

Hopkins, D., Higham, J., Orchiston, C., Duncan, T. (2019)

Practising academic mobilities: Bodies, networks and institutional rhythms

Geographical Journal

https://doi.org/10.1111/geoj.12301

Access to the published version may require subscription.

N.B. When citing this work, cite the original published paper.

Permanent link to this version:

http://urn.kb.se/resolve?urn=urn:nbn:se:du-30370 


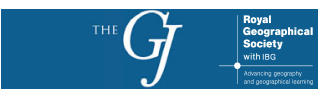

\title{
Practising academic mobilities: Bodies, networks and institutional rhythms
}

\author{
Debbie Hopkins $^{1}$ (D) | James Higham ${ }^{2,3}$ (D) | Caroline Orchiston ${ }^{4}$ (D) | Tara Duncan $^{5}$ (iD
}

${ }^{1}$ School of Geography and the Environment, University of Oxford, Oxford, UK

${ }^{2}$ Department of Tourism, University of Otago, Dunedin, New Zealand

${ }^{3}$ University of Stavanger, Stavanger, Norway

${ }^{4}$ Centre for Sustainability, University of Otago, Dunedin, New Zealand

${ }^{5}$ Dalarna University, Falun, Sweden

Correspondence

Debbie Hopkins

Email: debbie.hopkins@ouce.ox.ac.uk

\begin{abstract}
Notions of what a successful academic should be doing - researching, publishing, teaching, serving the academic community - are often dependent upon particular practices of corporeal mobilities. These practices discursively and materially connect historically situated academic mobilities with the "modern," globalised university system. At the same time, there is increasing attention being paid to the "hypocrisy of hypermobile academics" - often reliant on high-carbon aeromobilities - in light of the unprecedented and urgent need to decarbonise transport to limit warming to $1.5^{\circ} \mathrm{C}$. Using qualitative material gathered from one academic institution in Aotearoa New Zealand, we pay attention to the politics of academic mobilities at multiple scales, from the academic body, to social/family networks, and institutional rhythms. We contribute to the growing body of work that reflects on academic practice, and argue that detailed understandings of these processes are required to overcome the so-called "climate hypocrisy" of high-carbon academic work-related travel.
\end{abstract}

\section{K E Y W O R D S}

Aotearoa New Zealand, climate hypocrisy, internationalisation, qualitative interviews, travel, work

\section{1 | INTRODUCTION}

Transport has an uneasy relationship with efforts to reduce greenhouse gas (GHG) emissions. Unsustainable modes of transport, including private motorised vehicles and airplanes, dominate mobility practices prioritised through governance, infrastructure, finance, and social norms. While international and domestic aviation account for lesser total GHG emissions than road transport (10.6\% vs. $72 \%$; Sims et al., 2014), air transport emissions are produced by the travel practices of a small minority of the global population. Academics, scientists, and researchers - particularly those working on questions of sustainability, climate change and energy - are under increasing scrutiny, for what some are calling "climate hypocrisy": the high carbon mobility practices of those working to reduce GHG emissions. As with the system of automobility (Urry, 2004), aeromobilities are normalised within and beyond the academic sector. Decarbonising academic mobilities requires a detailed understanding of how and why academic mobilities are performed, the everyday experiences and impacts of academic travel, and the mechanisms that support or prevent academic mobilities.

Demand for internationalisation permeates academic work; from undergraduate enrolment to staff recruitment. An "international reputation" is frequently listed in employment and promotion criteria, and this is often bound up with corporeal mobility to create and sustain socio-professional networks. Yet the practice of academic mobilities is not evenly distributed or experienced. The capacity to engage in academic mobilities often requires a multitude of overlapping mechanisms of support that are unequally experienced across career stage, employment status, gender, geography, discipline, or institution. Despite growing awareness of the contribution academic travel makes to GHG emissions, and calls for reduced air travel, expectations of or desire for "co-presence" remain (Higham et al., 2019; Urry, 2002), creating a vicious cycle of expected/ 
desired (hyper)mobility (re)enforced by mobility-as-status and mobility as a stage on which the "successful" (in-demand, busy) academic performs.

In this paper, we contribute to the growing body of work that reflects on academic practice, and argue that its focus on Euro-American academic institutions has overlooked those for whom mode shift (e.g., to train travel) is unavailable, but where globalised expectations of mobility remain, thus sustaining dependence on highly polluting (extreme) long-haul air travel. ${ }^{1}$ This paper extends current understandings of the mechanisms that support and prevent academic work-related travel, and in doing so pays attention to the politics of academic mobilities at multiple scales from the individual (academic) body to social networks; and to the rhythms of academic practice.

\section{1 | Mobile work}

In contrast to discretionary leisure travel, travel for business purposes is often legitimised as an unpreventable part of international systems of enterprise (Faulconbridge \& Beaverstock, 2008; Wickham \& Vecchi, 2009). Businesses, organisations, and institutions may be dependent on interactions between people working and living in geographically dispersed locations (Gustafson, 2012). Knowledge-intensive businesses in particular are thought to require networks through which knowledge can be created, accumulated, and disseminated (Miles et al., 1995), and for which norms demanding face-to-face interactions are dominant (Castells, 2010; Urry, 2003). As a consequence, business travel is often perceived to be an important part of business competitiveness, sales, and customer engagement (Economist Intelligence Unit, 2013).

Processes of globalisation, technological innovation and the (rapid) diffusion of high-speed transport modes have prompted new routines and rhythms of mobility practices and patterns of work. Ever-more-complex work-life configurations see transnational relationships, family, and social networks extending demand for corporeal mobilities (Viry \& Kaufmann, 2015). At the same time, globalised economic and social processes have contributed to the construction of identities that support such mobilities: those of a "(hyper)mobile, successful professional." Within academic communities, mobilities are not only linked to contemporary processes of globalisation, but have long been an important part of scientific inquiry (Heffernan \& Jöns, 2013), with evidence of mobile networks dating to Ancient Greece (e.g., Bauder, 2015). Such historical embeddedness provides a powerful rationale and a taken-for-grantedness of mobility as part-and-parcel of an academic career.

Geographers have highlighted the importance of spatial mobility for the overlapping functions of producing and disseminating scientific knowledge (Livingstone, 2003; Meusburger et al., 2010). Yet while the notion of academic mobility is not new, the rate and volume of such mobilities has raised its impact on global carbon budgets (Byram \& Dervin, 2008), and health and wellbeing (Cohen \& Gössling, 2015). Interest in how and why academics travel has led to examination of global knowledge networks and diasporic scientists (Larner, 2015), centres of knowledge (Jöns, 2008, 2009), conference tourism (Høyer \& Næss, 2001), and international migration (Bauder, 2015). Research has shown how employment circumstances (e.g., precarity), career stage (e.g., early, mid, late), and gender affect the routines, rhythms, and types of mobility (Bauder, 2015; Hoffman, 2007). However, there has been less focus on the embodied experiences and practices of academic workrelated mobilities, and the ways through which discourses of globalisation and internationalisation are being used to legitimise the need for (hyper)mobile academics which privilege some while excluding others.

There are increasing pressures to prove and promote the relevance of academic work, requiring "considerable personal investment in building a body of work, a reputation, as well as maintaining social and professional relationships across time and space" (SIGJ2 Writing Collective, 2012, p. 1056). Global networks and the accumulation of social capital are argued to be central to the development and maintenance of "successful" academic careers (Larner, 2015). Consequently, the mobilities of academics become entwined with the accrual of "prestige and credibility" (Bauder, 2015, p. 85) and are "stimulated by a desire for professional socialization" (Mahroum, 2000, p. 26). The frequent mobility of established scholars thus (re)enforces its dominance as a symbol of a successful career and an aspirational practice for junior colleagues (Bauder, 2015). The requirement for academic mobilities is stabilised through various structural mechanisms, including the assessment of research performance, and prestigious research grants (e.g., Marie Skłodowska-Curie Actions), where international network building and collaboration are a critical component, emphasising the need for, and values attached to, academic travel and its various affordances. Internationalisation is often proven by way of affiliations, networks and collaborations (Larner, 2015).

\section{2 | Climate change, wellbeing and academic mobilities}

Climate change is both historically situated (e.g., from past emissions) and future focused (e.g., forecast impacts). Gases emitted locally and cumulatively are shared between regions and countries, and problematically, the "global commons." 
The burden of climate change is also not equally experienced: it is a hugely complex, (super)wicked challenge for contemporary society (Gardiner, 2011; Levin et al., 2007). In addition to well documented biophysical impacts, climate change is strongly related to rising inequalities and growing vulnerabilities, to conflict for resources and forced mass migration (Reuveny, 2007).

The burning of fossil fuels, which underpins high consumption and highly mobile lives, is a core contributor to global GHG emissions. In 2017, 4 billion passengers flew on scheduled flights (World Bank, 2019). Yet it is thought that just 6\% of global citizens will fly at some point in their $\operatorname{life}^{2}$ (Farrier, 2013). Domestic and international aviation accounted for $10.62 \%$ of direct GHG emissions (GtCO2 eq/year) in 2010 (Sims et al., 2014) but total impacts are likely to be far greater (e.g., including the formation of persistent linear contrails and aviation-induced cloudiness; Lee et al., 2009). Technological interventions to reduce transport emissions are unlikely to achieve radical reductions in the required timeframe (Sims et al., 2014), therefore behavioural change - such as reduced (aero)mobilities - will be critical to achieving rapid and radical carbon abatement (Capstick et al., 2014). However, as scholarship on automobility has shown, systemic lock-in to the dominant regime requires collective action across scales, while also acknowledging differential impacts and intersections with questions of justice and equity.

Responding to climate change and reducing the carbon-intense lifestyles of a hypermobile minority of society is a moral and ethical responsibility (e.g., Shue, 1993). This is supported by calls for reflexive practice among academic communities - particularly those researching environmental topics (e.g., Caset et al., 2018). In Aotearoa New Zealand, ${ }^{3}$ the Education Act (1989) positions academic institutions as the "critic and conscience of society," yet to date, there has been little critical reflection on the high-carbon practices of academics in the performance of their job, in Aotearoa or beyond (exceptions include: Caset et al., 2018; Higham et al., 2019; Hopkins et al., 2016; Nevins, 2013; Stohl, 2008). There are, however, burgeoning networks of scholars (e.g., "Flying Less"4), vocal champions (e.g., Anderson, 2013), and research groups (e.g., Tyndall Centre for Climate Change Research: Le Quéré et al., 2015; DEMAND Centre: Strengers, 2014) pointing to the ironies and hypocrisies of global academic mobilities. The need for sustained emissions reductions, and the role of academic air travel therein, forms the motivation for this paper as there is a critical need to better understand the dynamics and circulations of norms, values, structures, and practices that enable and constrain, (re)enforce, and promote academic work travel.

The intersection between environmental sustainability and well-being, particularly relating to business travel (e.g., Cohen \& Gössling, 2015) and neoliberal academic work (Davies \& Bansel, 2005) is well established. Eyears (2017) points to the mental health issues that can go hand-in-hand not only with work-related stress, but also with business travel by way of jet lag, poor sleep and diet, reduced support networks, and separation from home and family. These factors are amplified by concerns about speaking out to colleagues for fear of being perceived as "unable to cope" with the pressures of the job, and because "stress is constructed as a problem for individual workers to solve" (Davies \& Bansel, 2005, p. 51). Given the pressure to conduct and publish research, create and sustain networks, and teach at the highest of standards, travel and time away from home can separate workers from their social and support networks. Moreover, travel-for-work can involve intense schedules - to maximise the "value" and "use" of time away from the office and home, and to justify the cost of travel, and for some, associated carbon emissions, while often also minimising the duration of time spent away from home.

\subsection{The politics and practice of mobilities}

Mobilities scholarship provides useful conceptual tools for the investigation of the politics and practice of contemporary academic mobility. While data quantifying acts of "being mobile" characterise the scale of the issue, interrogating the embodied and spatialised dimensions of mobile practices may offer detailed understanding of both particular practices, and "the more theoretical sense of the social as it is embodied and habitualised" (Cresswell, 2010, p. 20). The meanings attached to mobilities are deeply held, and include both individual and collective perceptions, experiences and representations, which may be "relational, coding movement and its attendant mobile lives and resources within particular contexts" (Nikolaeva et al., 2018, p. 7). Importantly for the current research, this scholarship uncovers the structures, governance, historical contexts, and power relations which intersect with the potential to "lock in" particular practices of mobility that, in the context of academic mobilities, are closely tied to hegemonic frames of success, importance, and professionalism.

Mobilities are often connected with particular subject identities: for instance, that of a "successful" academic might be (partly) characterised by specific performances of mobility (e.g., regular attendance at disciplinary conferences), and include diverse, established and embedded mobile practices. Cresswell (2010) notes that popular connotations of mobility focus on its fluidity, when it is frequently accompanied by frictions, instabilities, and power asymmetries, for instance, affording mobility to some, while also rendering others (temporarily) immobile. This might be understood by way of departmental 
and institutional funding regimes for conference attendance which may privilege particular types of academic work(ers) over others. Similarly, frictions will not be experienced in the same way, but are steeped in politics, from the bodily, to the social and departmental arrangements and disciplinary configurations. There are numerous examples of exclusionary politics preventing academics from some countries crossing borders (e.g., USA's controversial travel ban - Executive Order 13769) to enter, leave, or travel through (e.g., Nicolson, 2018).

The politics of mobilities have been adopted as a theoretical frame by scholars examining flows of academic bodies, labour, and knowledge (e.g., Carrozza et al., 2017; Enriquez-Gibson, 2018). Enriquez-Gibson (2018, p. 2), for example, emphasises the "friction of being othered or othering that is experienced through the body whilst on the move as a mobile academic" in an auto-ethnographic account of a body-on-the-move. This work brings into conversation the politics of academic mobility with Henri Lefebvre's (2004) rhythmanalysis, and its analytical attention to the repetitive and rhythmic. The rhythms and routines of academic mobility practice are both stable and erratic; for some, such practice will be regularly aligned flows of disciplinary or topical conferences, ${ }^{5}$ departmental or institutional funding patterns, ${ }^{6}$ teaching terms, school holidays, and seasons. These (in)compatible rhythms may generate a desire to be on-the-move (however briefly), to not "miss out," and to prove and/or strengthen international networks.

\section{2 | METHODOLOGY AND METHODS}

Aotearoa presents an interesting case study for examining academic mobilities as it sits outside of the historically dominant academic centres of Europe and North America, and the emergent bases in Asia. Yet Aotearoa's academic institutions are globally recognised, and were established in the style of historical English universities. Culturally, Aotearoa shares many traits with European countries due to its colonial past and present, as well as inward migration. However, it also has distinct traits that relate not only to its indigenous Māori heritage, but also to cultures of mobilities, such as the "Overseas Experience" (e.g., Wilson, 2014), that have been attributed to physical remoteness to much of the world, and Aotearoa's relatively small population (c. 4.8 million; StatsNZ, 2018). Thus, Aotearoa shares some cultural attributes and practices with many countries of the "North"/"West," while also being faced with the tyranny of distance from these countries.

The research was conducted at the University of Otago, Aotearoa, a research-intensive institution with its main campus in Dunedin, on the lower South Island. Otago is Aotearoa's oldest and only collegiate university, with 20,000 students, approximately $15 \%$ of whom were born outside Aotearoa (University of Otago, 2016a); the proportion is much higher for academic staff. ${ }^{7}$ Further details about the University case study site are provided in the Supporting Information. A qualitative approach was adopted to gain detailed, in-depth perspectives on academic mobilities. Semi-structured interviews were conducted with respondents sampled by a stratified random procedure. All interviews were digitally audio-recorded, and fully transcribed by a professional transcription service. The transcribed interviews were independently coded by all four members of the research team searching for themes emerging from the material. The qualitative empirical material was examined by way of thematic, interpretive analysis. The Supporting Information includes more details of the sampling and analytical procedures, including a summary table (Table S1) of the interviewed staff. We examined how and why academic mobilities are performed, the everyday experiences and impacts of academic travel, and the mechanisms that support or prevent academic mobilities. Through these analyses, we contribute detailed understandings of contemporary academic mobilities from beyond the traditional Euro-America academic centres.

\section{3 | PERFORMING ACADEMIC MOBILITIES}

Our interviews provide evidence of the wide-ranging professional activities that "just keep you moving" (A6, associate professor, male, commerce) as part of an academic career, which include conference/workshop attendance, research project meetings, service position responsibilities, professional development courses, supervisory and/or examination roles, and fieldwork. The explicit, formal rationales for mobility appear to be historically and geographically consistent, with tasks broadly relating to the production and/or dissemination of research (e.g., Jöns, 2009). Academic mobilities, however, are performed in ways that are consistent with the ideologies, meanings and mechanisms of contemporary (academic) life; both enabled and constrained by layers of individual, collective, and institutional norms operating across spatial scales, and in tandem with modern cultures of mobility (Urry, 2000).

Within this research, we heard stories that framed travel for academic work as both "absolutely essential" (B5, professor, male, humanities) and an "inevitable consequence" (A3, senior lecturer, male, commerce) of a "successful" academic 
career. These frames characterise some of what Cresswell (2010) refers to as "motive force"; the participants are neither compelled to travel nor choosing, but offer justifications for mobility that become part of their complex, contradictory stories of academic mobility, with force coming from institutional discourse, disciplinary norms, research matter, personal ambition, and capabilities, among other factors. It was suggested that the frequency, duration, distance, and purpose differ by career stage in particular. This was characterised by a senior lecturer (D4, female, health science), who noted that: "the further up the food chain you get the more you travel. Absolutely, one hundred percent." Such perceptions, connecting (hyper)mobilities and discourses of success, progression, and seniority, work to entrench the invitations for and practices of work-related travel within discourses of career progression. Thus, the practice of travel and its various representations become codified as desirable academic practice and therefore academics who are more mobile may be perceived to be more successful than their less-mobile peers.

The frequency of travel was seen to be changing - both greater restrictions due to reductions in institutional funding, and expectations of enhanced mobilities, often linked to the need to be "competitive on the global stage." This misalignment between expectation to and funding for travel exposed a number of issues, particularly for more junior scholars, some on insecure contracts, with self-financing of travel identified as a worrying trend. Where funding for travel becomes entangled with seniority and external grant success, it can go further to promote travel as a sign of prestige. Academics practice mobility in different ways, but "the [successful] academic" was largely viewed to be a corporeally (hyper)mobile character. We move on to examine the impacts, implications, politics, and practices of academic mobilities at three divergent sites of analysis: (academic) bodies, social networks, and institutional rhythms, and show how academic mobilities are contingent on, and impact upon a variety of people, places, networks, and institutions, and their distinct rhythms and capabilities.

\section{4 | EFFICIENCY, PRACTICES AND (ACADEMIC) BODIES}

Our research points to the various scales at which the impacts of work-related mobilities play out. The first of these we are calling mobile academic bodies; the embodied and experiential dimensions of work-related travel underpinned by logics of "efficiency," "success," and "busy-ness." The "essential role of the body" for meetings in the global workplace has been described by Strengers (2015); however, our work takes this further, to show how the body is affected by and affects the mobilities of academics. We find intersecting pressures of extreme "mobile workplace efficiency" play out at the scale of the body. Notions of efficiency, optimisation, and value were used to discuss mobility practices in terms of time, money, and occasionally, carbon. This is consistent with the work of Davies and Bansel (2005) who point to the practices of academic work intensification linked to discourses of productivity and efficiency; but our research also highlights the intersections with emotional geographies of academic mobilities including, for instance, fatigue and exhaustion.

The first level at which the mobile academic body is made visible is by way of "efficient travel," which means "a tendency to ... just pack in as much as possible and come back exhausted" (B5, professor, male, humanities). This practice sometimes involves short-duration, long-haul travel to Asia, Europe, or North America, and "efficient" trip-chaining of activities. The explanations and justifications for these practices were wide ranging. The timing and inflexibility of teaching and other institutional responsibilities (lab management, research supervision etc.), discussed further below, provided one type of rationale for short travel, and such travel tended to be due to "prestigious" invitations and other so-called "unpreventable" travel - defined as such by individuals, departments, institutions, or a combination of all three. However, other rationales intersected work pressures, including expectations of key university, divisional, or departmental actors that academics should be "efficient" with their travel to justify costs of travel, and the desire of the participant to be efficient with their time away from home/work.

The types of mobilities that are performed by some of our participants (e.g., extreme long-haul air travel) require - or are most suited to - agile, able-bodied individuals, unencumbered with aids (e.g., walking sticks), objects (e.g., heavy suitcases), or dependents (e.g., children). Being encumbered with material items (e.g., suitcases), and the logistics of airport, train stations, and other infrastructures, further exacerbated the strain on the (academic) body as part of these mobilities: "humping around with suitcases from airports to somewhere else; or railways stations, especially dragging suitcases up staircases at railways" (A5, male, associate professor, commerce). The assemblage of bodies, technologies and objects on the move has been identified in a range of contexts, including walking, cycling, and train travel (e.g., Bissell, 2010, 2018), and expose the multiple ways that these enable and constrain mobility. To be most "efficient" in the context of academic 
travel involves discourses of healthiness, capability (skills and bodily), and freedom from "things" (e.g., bags, mobility aids) and "people" (e.g., children).

While short-term bodily impacts of travel are often recognised in the literature, our research found lasting and long-term implications of such mobilities. For instance, following 30 hours of travel to northern Europe, a professor in commerce (A7, male) stressed how:

I didn't know what time of day it was and I didn't know what time of day it was when I got back. I think that probably killed my productivity for another couple of weeks after I went as well ... my body clock was thrown out for two or three weeks after I got back, too.

This short-term "efficiency" causes longer-term "inefficiencies": the lasting effects of long-haul travel were associated with time differences and impacts of jet lag which affected our participants differently. Thus, the effects of work-related travel are not confined to time spent on-the-move, and away from home/work, but extend into the weeks following travel, and also creep into planning and coordination prior to travel. This might include tasks such as preparing presentations, but also organising travel, emailing colleagues, spending time with family and friends in preparation or compensation for separation, and mentally and physically preparing for travel. This could be interpreted through Edensor's rhythm/arrhythmia, with extreme long-haul travel requiring adaptation to new, unfamiliar rhythms, causing frictions in existing rhythm, creating new rhythms, and leading to "improvisatory reactions ... instilled by training and repetition" (Edensor, 2015, p. 167). Thus, the clashing temporalities and daily rhythms become interrupted by work-related travels.

While on-the-move, participants spoke of "feeling like cattle" and "being cramped up on a plane and the awful food" (A6, associate professor, male, commerce), which sits in stark contrast to discourses of prestige, esteem, and glamour of extreme aeromobilities (e.g., Cohen \& Gössling, 2015). Physical bodily effects of long-haul travel were described by one professor, "your knees start to seize up or ankles start to swell" (B1, male, humanities) and "I get nose bleeds on planes" (A7, professor, male, commerce). This was remedied by some participants by medicating to prevent travel sickness, with lasting side effects and implications for well-being.

Not only were the practices of being mobile problematic for some, but also the disruption of routines of self-care including sports participation, diet, and support networks: "There's the health concerns about travelling, being away from family" (A3, senior lecturer, male, commerce). These were articulated as "massive compromises," with one participant stating that while at home he swam daily, "you can't exercise while you are travelling" (C3, professor, male, science). Despite these bodily and emotional experiences of academic mobilities, on the whole, our participants tolerated these impacts, stating that travel was necessary and inevitable - bodily experiences that ranged from mild discomfort to strong physical and emotional reactions did little to reduce or prevent academic mobilities for some, but are likely to have lasting implications - including precluding other's mobilities. Such findings signal the complexities of reducing work-related mobilities where our participants tolerate often extreme bodily, emotional, and social impacts because of the perceived importance of travel.

\section{5 | NETWORKS, PROXIMITIES, AND CARING}

Social networks appear to operate as sources of both force and friction for academic-work-related mobilities. For some of our participants, family and friends overseas were an additional source of motivation to engage in travel, and became part of "trip chaining" activities, to gain maximum "value" from travel for work. Yet tensions also emerged. For those with caring responsibilities, family support became a critical part of overseas travel, whereby family members took over caring responsibilities to enable participation. Within an increasingly internationalised and competitive academic landscape, imperatives to work overseas prevail, and this further exacerbates the movement of those seeking employment opportunities, particularly junior scholars.

\section{1 | International networks: Being "part of the club"}

Articulated mobility practices were dominated by the proclivity of highly mobile academic lives and identities. Participants spoke of undergraduate study, postgraduate study, and academic positions undertaken in multiple countries, contributing to highly dispersed social and professional networks. International pathways are "a process. Something that I could never have predicted. It just happened. One thing has led to another and doors have opened at certain times" (B5, professor, male, humanities). These types of globalised personal and professional networks can result in normalised patterns of 
hypermobility, with routines that include returning to previous institutions and home countries, as well as seeking out new opportunities and connections. Extreme long-haul aeromobilities were framed as not only an inevitable consequence of academic careers, but also of living in Aotearoa. Many participants had worked in institutions across Europe, North America, Latin America, Asia, and Africa. These "circular academic mobilities" (Jöns, 2009) and geographies of academic labour establish practices, norms, and expectations of mobilities that are challenged by the geographical distance of Aotearoa to so-called academic centres (i.e., Europe and North America), but create social networks that replicate mobile practice over time.

The ability to develop and maintain connections with international communities was noted as being a critical aspect of an academic career: "I think it's absolutely essential if you're going to have a serious career professionally, which means having connections" (B5, professor, male, humanities). This suggests that "success" becomes synonymous with networks of scholars, practitioners and communities, and stresses the need for collaborations, for which corporeal mobility was viewed as a critical component part (e.g., Strengers, 2015). It has previously been reported that innovations in air transport, and later virtual communications (e.g., Skype) have geographically extended these links, reinforcing the need to travel further (Urry, 2003, 2007). This discourse was evidenced in our research by a participant who noted that his "academic base" was in Europe, and therefore travelling there annually ensured critical "face-to-face" time with colleagues, conceptualised by Urry (2003) as "co-presence." This is particularly important in the light of international and mobile identities and the performed subjectivities of many of our research participants. Through these mobilities, colleagues became friends, blurring the social and professional networks, relationships, and identities. These types of relationship - developed over repeated academic travel - are difficult to replicate by other means. The travel becomes about more than the production and dissemination previously noted by Livingstone (2003) and Meusburger et al. (2010), but instead about socialities that exist through work-related mobilities.

Having an international profile was also defined in our research as "being part of the club," contributing to opportunities which in turn lead to progression: "[It is] important and as your career develops you become part of a club. You're in your particular specialty and your friends invite you and you invite them" (D1, professor, male, sciences). Thus, cultural capital (Bourdieu, 1986) may be accumulated by way of mobilities which in turn afford greater mobility through invitations, collaborations, and an international reputation, replicating cycles of (hyper)mobility for some (those "in the club"), while excluding others (those "out of the club").

\section{2 | Families near and far}

Different types of caring responsibilities emerged, from daily parental responsibilities, to elderly parents in different parts of the world. Family (broadly defined) can constrain, enable or provide a rationale for travel. For instance, family and friends who are able to support or take over caring responsibilities enable some degree of travel for work, yet the lack of such support mechanisms prevents, postpones, or complicates work-related travel. Moreover, family based overseas, and associated care and support of elderly parents and other relationships, can stimulate interest in travel. Such geographies of care (Milligan \& Wiles, 2010) expose diverse caring arrangements ("caring about," "caring for") that might include grandparenting responsibilities for and by academic workers.

Some participants noted the recruitment processes at Otago, and the complexities of recruitment in other geographically isolated institutions elsewhere in Aotearoa, but also in more remote locations across the world. Such recruitment strategies mean that regular international travel is motivated by professional and social/relational intentions. A professor from commerce (A7), for instance, highlighted the promises made during recruitment of international academic staff:

One of the key things that is important to persuading good staff to come to the end of the world if their family is in Europe or US or something like that, is that there is travel available for them in order to maintain family ties.

The variety of family configurations, which include parent(s), grandparent(s), friends, and other relatives, was used to explain capacities to engage in work-related travel. A lecturer from commerce (A2) pointed to her husband's shift work, and a lack of local family connections as reasons why international travel could not be undertaken. The local family support was also reiterated by a male academic, who signalled the pressures to remain local for conferencing in order to support his wife: "we're relatively new to New Zealand. We don't have a family support network. So, if I'm away and my wife feels unwell then it's really hard" (A3, senior lecturer, commerce). The use of family members to enable participation in work-related travel was noted by a senior lecturer in health science, whose Auckland-based parents - a three-hour flight 
away - would travel to Dunedin to care for her child. This type of interaction shows how work mobilities may contribute to connected and networked mobilities of others, such as those of dependents or family members, to support and enable: "As she's [participant's daughter] got older I've just gone by myself. Usually my father has been really nice and come down and looked after her" (D4, senior lecturer, female, health science). The availability of such support mechanisms is not the whole story, however; they often intersect with complex feelings of guilt/shame, and reciprocity, and while enabling some mobilities, these can be restricted, with the same participant noting that: "Whenever I'm travelling, it's very brief. Go there, do what I have to do, come back. It's all working around childcare."

\section{6 | SCALES, GEOGRAPHIES AND INSTITUTIONAL RHYTHMS}

The geographical remoteness of Aotearoa, time zones, and asymmetries with northern hemisphere academic terms were all identified by our participants as complexities to participating in both virtual ${ }^{8}$ and corporeal mobilities. The distance from other academic centres was articulated by way of embodied experiences of extreme long-haul travel, of time differences making communication with colleagues across the world difficult, if not impossible, and of incongruent institutional calendars creating an obstacle to attending conferences held in Europe and North America.

The perceived need to attend international conferences was sometimes challenged by teaching commitments and the incongruence between academic rhythms, whereby northern hemisphere summer conferences often align with heavy periods of teaching in southern hemisphere institutions. Yet the dominant framing of conferences as an essential activity for academics prevails. Therefore, mobilities depend on support from colleagues, to share teaching and help one another to accept invitations. Such processes, however, also feed into patterns of short-duration long-haul travel that were expressed by many of our participants. For instance, a professor from commerce (A7, male) discussed his travel to Iceland, a 36,000 km return flight.

I have been to Iceland once, Iceland inside a week! Which was nonsense, it really was nonsense! [But] it was May, it was the middle of teaching. So, I managed to get somebody to cover my teaching for one week. I mean, it was stupid.

Participants spoke of "negotiating" to cover teaching and be able to travel during the term. However, this was also noted as being "virtually impossible," particularly by those within smaller departments, or without colleagues to cover specialist topics. This could also replicate inequalities within departments, where junior and often precariously employed academics take on the teaching of established senior staff, to enable their attendance, while remaining immobile (or less mobile) themselves.

The politics of conference funding - with most participants relying on limited departmental funds - can also result in the prioritisation of international conferences at the expense of local or regional conferences: "I seldom go to the local conference ... I tend not to now because of budget restrictions. I don't want to waste my dollar allocation in going to a local conference" (A5, associate professor, male, commerce). Thus, while local conferences were often preferred by participants with caring responsibilities, these were seen to be less significant than international conferences, and one participant noted: "I guess I'm being compared to people who are presenting at an international level and certainly conference proceedings count ... So yeah, I do feel some of that pressure" (A2, lecturer, female, commerce). Such preference for international over local conferences due to perceived prestige is problematic for efforts in carbon reduction, but the underlying discourse of internationalism promotes (extreme) long-haul aeromobilities, and this needs to be confronted and repositioned if academic carbon emissions are to be reduced at the scale required.

The pressure extended beyond the participant's specific department, school, or institution towards the mobility practices of international colleagues. For instance, an associate professor in commerce (A6, male) argued that postgraduate students in Europe are more connected than professors in Aotearoa:

We know PhD students in Austria and they're going to three international conferences a year... even our professors here are less connected than a lot of the $\mathrm{PhD}$ students over there.

This could identify an expectation of higher mobility for senior compared with junior academics as noted earlier, and provides evidence of the globalised norms of academic mobility, which some Aotearoa-based academics seek to replicate, but with greater carbon dependency. 


\section{7 | DISCUSSION AND CONCLUSION}

In this paper, we have uncovered the complex individual, social, and institutional mechanisms that enable, constrain, optimise, and (re-)enforce academic mobilities. Our research shows how bodily experiences of travel bring together particular socio-material (e.g., "heavy" suitcases), infrastructural (e.g., staircases, airports), and bodily (in/capacities) features, and suggests that efficiency is performed through specific configurations of these. Our participants illustrate perseverance, describe tactics for negotiating the various (material, bodily, emotional, social) challenges of mobility, and point to the support mechanisms, which are all operationalised in order to enable participation. From these findings, we argue that discursive and material politics occurring at multiple scales simultaneously (re-)enforce practices of academic mobilities that are highly uneven, but fit with logics of internationalisation, globalisation, and neoliberalisation. Such findings suggest that actions to decarbonise academic mobility will require sustained structural reconfigurations that realign dominant discourse with sustainable practice.

Mobilities create, construct, and (re-)enforce dominant subject identities; "the jet-setter," "the successful academic," "the globally recognised scholar." They inform and are informed by dominant notions of "the good academic" with activities linked to becoming "part of the club" as much as the production or dissemination of research. To do so, our participants put their "body on the line," enduring embodied emotional effects/affects that include, but are not limited to tiredness, disorientation, aches, pains, bleeds, loneliness, and anxiety. These are compounded by discourses of efficiency, leading to chaining practices to prove the "value" and "worth" of the travel. This, Davies and Bansel (2005, p. 51) note, is indicative of the neoliberal academic workplace:

(Where) workers ... might be understood as exploiting their own bodies and capacities, that is, working to prove themselves capable in a workplace culture where intensified practices of work and their demands are increasingly impossible to meet without significant cost to the health and well-being of the worker.

These findings have important implications for decarbonising academic mobilities, and suggest the need for a recalibration of what academic travel is for, what it means, and how low-carbon alternatives can be fostered - that goes further than "travel substitution" (e.g., virtual attendance), which overlooks the more-than-dissemination/communication aspects of academic mobilities. Moreover, challenging these dominant ways of thinking and doing could offer further (bodily, emotional) benefits for academics.

Our research found different meanings, values, and expectations of travel across the four academic divisions. For instance, the sciences articulated an "absolute necessity" for travel, particularly for $\mathrm{PhD}$ and post-doctoral fellows for whom conference attendance was a central part of securing a job. Professors who led laboratories argued that their labs needed to be represented at disciplinary conferences, and spoke of the challenges of being accepted - a key point of difference from some other disciplines where conferences were less competitive and prestigious. Likewise, the need to travel for research purposes varied substantially across our cohort, with some participants undertaking archival research around the world, while others were largely desk based in Dunedin. Thus, within the humanities and social sciences, there was varying necessity to travel for research purposes. Therefore, there is considerable heterogeneity in mobility practice within and across disciplines and career stages, which needs to be accounted for.

The symbiotic relationship between the perceived need to compete on a global academic stage and to travel to achieve this requires that academics overcome potential obstacles to travel that may emerge from family and caring responsibilities, competing institutional responsibilities (e.g., teaching and supervision), and departmental dynamics in terms of funding regimes, reward, and recognition processes. Storme et al. (2017) have previously noted the obligation of corporeal presence to create and sustain professional networks in Flemish and Danish contexts; such commitment to mobilities from an Aotearoa perspective is likely to require significantly greater duration of travel and associated externalities. Moreover, the mobilities of some may lead to immobility of others, and this might play out at the departmental scale, where some ("successful") academics travel, while other ("less successful") academics do not. Those who remain may well take on additional teaching and service responsibilities in lieu of their mobile colleagues, and such demands may further fall to fixed-term, teaching-only, early-career (precarious) academic positions, pointing to the need for further consideration of the political economy of academic mobilities (Bauder, 2015; Carrozza et al., 2017).

For some academics, the practice of work-related conference travel has become a taken-for-granted and routinised part of academic life. There is strong evidence to suggest that the legitimacy of academic mobility is maintained by academic institutions largely for reputational and academic excellence reasons, alongside issues of recruitment and retention of international staff who expect to maintain their networks across the globe. Academics and wider societal mobilities normalise 
frequent business travel as the hallmarks of a successful and important identity. Yet unlike business travellers who are often provided with cabin upgrades and airline lounge access for their travel, our cohort complained of extreme long-haul air travel in economy class, and of limited budgets for travel, which often required personal financing of some of the costs of work-related travel. This differs substantially from private sector business travel and has disproportionate impacts for junior scholars and others without the financial means to supplement their travel funding extending the asymmetry between the more- and less-mobile colleagues, while also raising important questions about how universities respond to their carbon emissions in an equitable way. Aotearoa-based academics appear to be replicating the mobilities of northern hemisphere colleagues, through an internationalisation discourse and mobile practice that promotes hypermobility, and face-to-face access and communication, over virtual mobilities with substantial implications for travel-related GHG emissions and their contribution to climate change.

Our sample represented the travel capabilities of an affluent, mobile population, not only with confidence and abilities, but also with tactics, strategies, and skills for reproducing and "surviving" extreme long-haul travel. While the empirical findings presented in this paper relate to a specific spatial and temporal context, the globalised networks of the academe, and the global pervasiveness of academic travel for conference attendance, particularly in countries of the global North, suggest that there may be commonalities with other geographical settings. It would be valuable to consider the fluidity of practices across space and time. Actions to respond to the unsustainable practices of academic aeromobilities - in terms of carbon, health, and well-being demand responses across these various domains and scales if the climate hypocrisy of academic travel is to be challenged. Cultures of academic practice need to be understood, and the ways through which these are supported by funding regimes, processes of recruitment, promotion, and standardised assessment, and dominant networks. Geographical sensitivities are required in thinking about responses to hypermobility, to include not only the southern hemisphere (e.g., Australia, Aotearoa) but also academics based in institutions in countries of the global South.

\section{ACKNOWLEDGEMENTS}

The authors would like to thank the participants of this research, and three anonymous reviewers and the Editor for their constructive feedback on, and engagement with earlier versions of this paper.

\section{ENDNOTES}

1 "Extreme" long-haul is used here and elsewhere in the paper to denote multiple long-haul flights chained together as required for travel from Aotearoa New Zealand to Europe, as opposed to one single long-haul flight (Higham \& Cohen, 2011).

${ }^{2}$ There are many assumptions embedded in this figure, and data are scarce. Nevertheless, this figure suggests that a small minority of the global population travel by airplane.

${ }^{3}$ Aotearoa is the Māori name for New Zealand, most commonly translated to mean the land of the "long white cloud." It is commonly used within Aotearoa New Zealand (with or without New Zealand) and there are growing calls for it to be added to New Zealand as the country's official name.

${ }^{4}$ On 28 April 2019, the "Flying Less" petition (https://academicflyingblog.wordpress.com/) for universities and professional associations to reduce flying had 615 signatories.

${ }^{5}$ In geography, for example, the Association of American Geographers conference in April annually, and the Royal Geographical Society (with IBG) in August annually.

${ }^{6}$ For instance, annual funding rounds with money expiring at the end of the academic year.

${ }^{7}$ There are no clear data on this, however the University of Otago website states that "70 per cent of our staff are international or have their higher degree acquired internationally" (University of Otago, 2016b, p. 14)

${ }^{8}$ For instance, European or North American based webinars and virtual conferences occurring in the middle of the night Aotearoa (Auckland) time.

\section{ORCID}

Debbie Hopkins (D) https://orcid.org/0000-0002-7778-8989

James Higham (D) https://orcid.org/0000-0003-1405-7035

Caroline Orchiston (iD https://orcid.org/0000-0002-3171-2006

Tara Duncan (D https://orcid.org/0000-0003-1845-7001 


\section{REFERENCES}

Anderson, K. (2013, April 12). Hypocrites in the air: Should climate change academics lead by example? Revisiting the 'climate-academic' on a plane argument [Web log post]. Retrieved from http://kevinanderson.info/blog/hypocrites-in-the-air-should-climate-change-academics-lead-byexample/

Bauder, H. (2015). The international mobility of academics: A labour market perspective. International Migration, 53, 83-96. https://doi.org/10. 1111/j.1468-2435.2012.00783.x

Bissell, D. (2010). Passenger mobilities: Affective atmospheres and the sociality of public transport. Environment and Planning D: Society and Space, 28, 270-289. https://doi.org/10.1068/d3909

Bissell, D. (2018). Transit lives: How commuting is transforming our cities. Cambridge, MA: MIT Press.

Bourdieu, P. (1986). The forms of capital. In J. Richardson (Ed.), Handbook of theory and research for the sociology of education. New York, NY: Greenwood Press.

Byram, M., \& Dervin, F. (2008). Students, staff and academic mobility in higher education. Newcastle, UK: Cambridge Scholars Publishing.

Capstick, S., Lorenzoni, I., Corner, A., \& Whitmarsh, L. (2014). Prospects for radical emissions reductions through behaviour and lifestyle change. Carbon Management, 5, 429-445. https://doi.org/10.1080/17583004.2015.1020011

Carrozza, C., Giorgi, A., \& Raffini, L. (2017). Brains and bodies on the move. A research agenda on precarious researchers' mobility. In T. Franca \& B. Padilla (Eds.), Transnational scientific mobility: Perspectives from the North and South. Lisboa, Portugal: Universidade Nova de Lisboa.

Caset, F., Boussauw, K., \& Storme, T. (2018). Meet \& fly: Sustainable transport academics and the elephant in the room. Journal of Transport Geography, 70, 64-67. https://doi.org/10.1016/j.jtrangeo.2018.05.020

Castells, M. (2010). Globalisation, networking, urbanisation: Reflections on the spatial dynamics of the information age. Urban Studies, 47, 2737-2745. https://doi.org/10.1177/0042098010377365

Cohen, S., \& Gössling, S. (2015). A darker side of hypermobility. Environment \& Planning A, 47, 1661-1679. https://doi.org/10.1177/ $0308518 X 15597124$

Cresswell, T. (2010). Towards a politics of mobility. Environment and Planning D: Society and Space, 28, 17-31. https://doi.org/10.1068/d11407

Davies, B., \& Bansel, P. (2005). The time of their lives? Academic workers in neoliberal time(s). Health Sociology Review, 14, 47-58. https:// doi.org/10.5172/hesr.14.1.47

Economist Intelligence Unit (2013). Business on the move: How globalization is changing the travel plans of European executives. Wales, UK: Global Corporate Payment.

Edensor, T. (2015). Rhythm and Arrhythmia. In P. Adey, D. Bissell, K. Hannam, P. Merriman, \& M. Sheller (Eds.), The Routledge handbook of mobilities (pp. 163-171). Abingdon, UK: Routledge.

Education Act (1989). Legislation: New Zealand Education Act. Retrieved fromhttp://www.legislation.govt.nz/act/public/1989/0080/latest/ DLM175959.html.

Enriquez-Gibson, J. (2018). Rhythms of academic mobility. Applied Mobilities. Advance online publication https://doi.org/10.1080/23800127. 2017.1416828

Eyears, J. (2017). Business travel and mental health: A wake-up call for employers. Occupational Health and Wellbeing, 69, 23. https://www.pe rsonneltoday.com/hr/business-travel-and-mental-health-a-wake-up- call-for-employers/

Farrier, T.. (2013, March 26). What percent of the world's population will fly in an airplane in their lives? [Online forum comment]. Retrieved from https://www.quora.com/What-percent-of-the-worlds-population-will-fly-in-an-airplane-in-their-lives

Faulconbridge, J. R., \& Beaverstock, J. V. (2008). Geographies of international business travel in the professional service economy. In D. Hislop (Ed.), Mobility and technology in the workplace. Abingdon, UK: Routledge.

Gardiner, S. (2011, October 20). The ethical dimension of tackling climate change. New Haven, CT: Yale Environment. Retrieved from http:// e360.yale.edu/features/the_ethical_dimension_of_tackling_climate_change.

Gustafson, P. (2012). Managing business travel: Developments and dilemmas in corporate travel management. Tourism Management, 33, 276284. https://doi.org/10.1016/j.tourman.2011.03.006

Heffernan, M., \& Jöns, H. (2013). Research travel and disciplinary identities in the University of Cambridge, 1885-1955. British Journal for the History of Science, 46, 255-286. https://doi.org/10.1017/S000708741200074X

Higham, J. E. S., \& Cohen, S. A. (2011). Canary in the coalmine: Norwegian attitudes towards climate change and extreme long-haul air travel to Aotearoa/New Zealand. Tourism Management, 32, 98-105. https://doi.org/10.1016/j.tourman.2010.04.005

Higham, J. E. S., Hopkins, D., \& Orchiston, C. (2019). The work-sociology of academic aeromobility at remote institutions: Networks, co-presence and proximity. Mobilities, https://doi.org/10.1080/17450101.2019.1589727

Hoffman, D. M. (2007). The career potential of migrant scholars: A multiple case study of long-term academic mobility in Finnish universities. Higher Education in Europe, 32, 317-331. https://doi.org/10.1080/03797720802066153

Hopkins, D., Higham, J. E. S., Tapp, S., \& Duncan, T. (2016). Academic mobility in the Anthropocene era: A comparative study of university policy at three New Zealand institutions. Journal of Sustainable Tourism, 24, 376-397. https://doi.org/10.1080/09669582.2015.1071383

Høyer, K. G., \& Næss, P. (2001). Conference tourism: A problem for the environment, as well as for Research? Journal of Sustainable Tourism, 9, 451-470. https://doi.org/10.1080/09669580108667414

Jöns, H. (2008). Academic travel from Cambridge University and the formation of centres of knowledge, 1885-1954. Journal of Historical Geography, 34, 338-362. https://doi.org/10.1016/j.jhg.2007.11.006 
Jöns, H. (2009). 'Brain circulation' and transnational knowledge networks: Studying long-term effects of academic mobility to Germany, 19542000. Global Networks, 9, 315-338. https://doi.org/10.1111/j.1471-0374.2009.00256.x

Larner, W. (2015). Globalising knowledge networks: Universities, diaspora strategies, and academic intermediaries. Geoforum, 59, $197-205$. https://doi.org/10.1016/j.geoforum.2014.10.006

Le Quéré, C., Capstick, S., Corner, A., Cutting, D., Johnson, M., Minns, A., Schroeder, H., Walker-Springett, K., Whitmarsh, L., \& Wood, R. (2015). Towards a culture of low-carbon research for the 21st Century (Working Paper 161). Retrieved from Tyndall Centre on Climate Change Research website: http://tyndall.ac.uk/sites/default/files/publications/twp161.pdf

Lee, D. S., Fahey, D. W., Forster, P. M., Newton, P. J., Wit, R. C. N., Lim, L. L., \& Sausen, R. (2009). Aviation and global climate change in the 21st century. Atmospheric Environment, 43, 3520-3537. https://doi.org/10.1016/j.atmosenv.2009.04.024

Lefebvre, H. (2004). Rhythmanalysis: Space, time and everyday life. London, UK and New York: Continuum.

Levin, K., Cashore, B., Bernstein, S., \& Auld, G. (2007, January). Playing it forward: Path dependency, progressive incrementalism, and the "super wicked" problem of global climate change. Paper presented at IOP Conference Series Earth and Environmental Science 6:50.

Livingstone, D. N. (2003). Putting science in its place: Geographies of scientific knowledge. Chicago, IL: University of Chicago Press.

Mahroum, S. (2000). Highly skilled globetrotters: Mapping the international migration of human capital. R\&D Management, 30, 23-31. https:// doi.org/10.1111/1467-9310.00154

Meusburger, P., Livingstone, D. N., \& Jöns, H. (2010). Geographies of science. Dordrecht, The Netherlands: Springer.

Miles, I., Kastrinos, N., Flanagan, K., Bilderbeek, R., \& den Hertog, P. (1995). Knowledge intensive business services. Users, carriers and sources of innovation. Manchester, UK: PREST.

Milligan, C., \& Wiles, J. (2010). Landscapes of care. Progress in Human Geography, 34, 736-754. https://doi.org/10.1177/0309132510364556

Nevins, J. (2013). Academic jet-setting in a time of climate destabilization: Ecological privilege and professional geographic travel. The Professional Geographer, 66, 298-310. https://doi.org/10.1080/00330124.2013.784954

Nicolson, D. (2018, August 28). For some, borders are now an insurmountable barrier to attending international academic conferences [Web log post]. Retrieved from https://blogs.lse.ac.uk/impactofsocialsciences/2018/08/28/for-some-borders-are-now-an-insurmountable-barrier-to-atte nding-international-academic-conferences/

Nikolaeva, A. A., Adey, P., Cresswell, T., Lee, J. Y., Novoa, A., \& Temenos, C. (2018). A new politics of mobility: Commoning movement, meaning and practice in Amsterdam and Santiago (Centre for Urban Studies Working Paper Series). Retrieved from https://dare.uva.nl/searc h?identifier=d593e70a-a100-481b-93c0-d0006b678783

Reuveny, R. (2007). Climate change-induced migration and violent conflict. Political Geography, 26, 656-673. https://doi.org/10.1016/j.polgeo. 2007.05.001

Shue, H. (1993). Subsistence emissions and luxury emissions. Law and Policy, 15, 39-60. https://doi.org/10.1111/j.1467-9930.1993.tb00093.x

SIGJ2 Writing Collective (2012). What can we do? The challenge of being new academics in neoliberal universities. Antipode, 44, $1055-1058$. https://doi.org/10.1111/j.1467-8330.2012.01011.x

Sims, R., Schaeffer, R., Creutzig, F., Cruz-Núñez, X., D'Agosto, M., Dimitriu, D., Figueroa Meza, M. J., Fulton, L., Kobayashi, S., Lah, O., McKinnon, A., Newman, P., Ouyang, M., Schauer, J. J. ... Sausen, R. (2014). Transport. In O. Edenhofer, R. Pichs-Madruga, Y. Sokona, J. C. Minx, E. Farahani, S. Kadner, K. Seyboth, A. Adler, I. Baum, S. Brunner, P. Eickemeier, B. Kriemann, J. Savolainen, S. Schlömer, von Stechow C. \& T. Zwickel (Eds.), Climate change 2014: Mitigation of climate change. Contribution of Working Group III to the Fifth Assessment Report of the Intergovernmental Panel on Climate Change. Cambridge, UK and New York, NY, USA: Cambridge University Press.

Stohl, A. (2008). The travel-related carbon dioxide emissions of atmospheric researchers. Atmospheric Chemistry and Physics, 8, 6499-6504. https://doi.org/10.5194/acp-8-6499-2008

Strengers, Y. (2014, June 4). Fly or die: Air travel and the internationalisation of academic careers [Web log post]. Retrieved from http:// www.demand.ac.uk/04/06/2014/fly-or-die-air-travel-and-the-internationalisation-of-academic-careers/

Strengers, Y. (2015). Meeting in the global workplace: Air travel, telepresence and the body. Mobilities, 10, 592-608. https://doi.org/10.1080/ 17450101.2014.902655

Storme, T., Faulconbridge, J. R., Beaverstock, J. V., Derudder, B., \& Witlox, F. (2017). Mobility and professional networks in academia: An exploration of the obligations of presence. Mobilities, 12, 405-424. https://doi.org/10.1080/17450101.2015.1116884

University of Otago (2016a). Quick stats. Retrieved from http://www.otago.ac.nz/about/quickstats.html.

University of Otago. (2016b, March). University of Otago Magazine, 42. Retrieved from https://www.otago.ac.nz/otagomagazine/otago598496.pdf Urry, J. (2000). Mobile Sociology. The British Journal of Sociology, 51, 185-203. https://doi.org/10.1111/j.1468-4446.2000.00185.x

Urry, J. (2002). Mobility and proximity. Sociology, 36, 255-274. https://doi.org/10.1177/0038038502036002002

Urry, J. (2003). Social networks, travel and talk. British Journal of Sociology, 54, 155-175. https://doi.org/10.1080/0007131032000080186

Urry, J. (2004). The 'system' of automobility. Theory, Culture \& Society, 21, 25-39. https://doi.org/10.1177/0263276404046059

Urry, J. (2007). Mobilities. Cambridge, UK: Polity Press.

Viry, G., \& Kaufmann, V. (2015). High mobility in Europe: Work and personal life. Basingstoke, UK: Palgrave Macmillan.

Wickham, J., \& Vecchi, A. (2009). The importance of business travel for industrial clusters - making sense of nomadic workers. Geografiska Annaler: Series B, Human Geography, 91, 245-255. https://doi.org/10.1111/j.1468-0467.2009.00318.x

Wilson, J. (2014). Flying Kiwis. A history of the OE. Dunedin, New Zealand: University of Otago Press.

World Bank (2019). Air transport, passengers carried. Retrieved from https://data.worldbank.org/indicator/is.air.psgr 


\section{SUPPORTING INFORMATION}

Additional supporting information may be found online in the Supporting Information section at the end of the article. Data S1. The Case Study.

Table S1: Aggregate Participant Information.

How to cite this article: Hopkins D, Higham J, Orchiston C, Duncan T. Practising academic mobilities: Bodies, networks and institutional rhythms. Geogr J. 2019;00:1-13. https://doi.org/10.1111/geoj.12301 